\title{
The D-Day landing of June 1944: extrat- ropical cyclones and surface winds in June 1944 compared with a climatology based on the Twentieth Century Reanalysis
}

\section{Christoph Welker, ${ }^{1}$ Melanie Bieli, ${ }^{2}$ Nicolas Piaget ${ }^{2}$ and Michael Sprenger ${ }^{2}$ \\ 'Oeschger Centre for Climate change \\ Research and Institute of Geography, \\ University of Bern, Switzerland \\ ${ }^{2}$ Institute for Atmospheric and Climate \\ Science, ETH Zurich, Switzerland}

\section{Introduction}

\section{Historical overview from a meteorological perspective}

Near the end of World War II, as the D-Day invasion of Normandy by thousands of ships was approaching, the whole enterprise was totally dependent on an accurate prediction of weather. The lives of more than half a million soldiers were at stake, as well as the fate of the war in Europe (for a very recent account on D-Day, see Atkinson, 2013). Under the pressure of these highly dramatic circumstances, six meteorologists working in three different teams were responsible for the D-Day forecasts. Their decision to go ahead would come down to the most important weather forecast ever made.

Operation Overlord, the operation that launched the invasion of German-occupied western Europe, would use allied air, naval and land forces. It was decided that this joint multinational undertaking should be accompanied by a combined effort on the weather forecasting side as well (see e.g. Douglas, 1952; Stagg, 1971; Petterssen, 2001). Three separate teams, from the British Meteorological Office (referred to as Dunstable group), the British Admiralty, and the US Air Force, were assembled by the Allied Supreme Commander, General (later US President) Dwight Eisenhower. They first made separate forecasts and then sought consensus in telephone conferences, with the British meteorologist James Stagg leading the debate and presenting the findings to Eisenhower - an early example of what is referred to as ensemble forecasting today.

While the Allied combat troops were waiting in a state of what their commander called 'suspended animation' (Cox, 2002), this group of forecasters had to decide if conditions (e.g. light winds and non-stormy seas) would permit the largest military invasion in history to go forward on 5 June 1944 or not. On top of that, the forecast of these conditions had to be made at least 2 days in advance - at a time when forecasting weather for several days and beyond was still unknown scientific territory, especially for the highly variable UK weather.

Given this background, Stagg and his team hoped for a stable 'blocking high' associated with persistent calm weather. However, as May turned to June, the placid weather turned into a 'forecaster's nightmare'. It was exceptionally stormy (e.g. Montgomery, 1948; Ambrose, 1994; Fleming, 2004), with conditions more like those during April. Under these conditions, climatology and analogue forecasts could not provide much of a guideline for the predictions. With D-Day approaching, the commanders became more and more anxious, and the three teams were struggling to arrive at a final consensus. Behind the scenes, during long telephone conferences over scrambled signals, critical differences among the weather forecasters, especially between the Norwegian Sverre Petterssen and the American Irvin Krick, were fought out in an atmosphere of increasing tension and occasional hostility (Cox, 2002). Krick's team consistently found historical analogues that called for acceptable weather on 5 June 1944. On the other hand, Petterssen's upper-air analyses and Douglas's intuition, both meteorologists working together at Dunstable, just as consistently indicated deteriorating weather (Ackerman and Knox, 2006).

Finally, the bleak, windy forecast that Stagg presented to General Eisenhower led to the postponement of the D-Day landings. However, at the time this decision was taken, the weather in the Channel region was still fairly calm, because the weak anticyclonic flow associated with the high-pressure system over the Azores was still prevailing. The decision to invade on 6 June was made in the morning of 5 June and was based on the forecast of a short period of improved weather that would open a small 'window of opportunity' for the assault. Indeed, the invasion weather on 6 June was marginally acceptable. The German army was caught by surprise and the landings on the Normandy beaches marked the beginning of the end of World War II.

\section{Reconstructing the D-Day weather - goals and questions}

The historical background of the D-Day landings sets the stage for our investigation of the weather conditions in June 1944. Our analyses are based on the Twentieth Century Reanalysis (20CR; Compo et al., 2011), a novel global atmospheric reanalysis which extends back to 1871 , as well as historical weather charts provided by the Met Office. The weather evolution during the D-Day landings is examined with emphasis on wind and atmospheric moisture, which we regard as the key variables determining sea swell and visibility in the landing area. Because historical reports stressed the uncommonly unsettled and stormy weather conditions over the British Isles and northern France during June 1944, the 'storminess' of this month is assessed in terms of cyclone frequency and near-surface wind speed in comparison to the climatology.

\section{The 20CR and objective cyclone identification}

\section{The 20CR data set}

Retrospective analyses (or reanalyses) have become an important tool in studying weather and climate variability. By incorporating a variety of measurement data into numerical models, they produce a temporally and spatially consistent synthesis of observations and analyses of variables that are not easily observed. To reconstruct the weather in early June 1944, we made use of the 20CR data set, which contains global weather conditions and their uncertainty in six-hourly intervals for the period from 1871 to present. Surface-pressure observations were combined with a shortterm forecast from an ensemble (with 56 ensemble members) of integrations of a numerical weather-prediction model using the Ensemble Kalman Filter technique to produce an estimate of the complete state of the atmosphere, and the uncertainty in 
that estimate. Monthly sea-surface temperature (SST) and sea-ice distributions from the HadISST data set (Rayner et al., 2003) served as boundary conditions. For further details on the 20CR refer to Compo et al. (2011). Among others, the 20CR data set was intended for the assessment of decadalscale climate variability. Furthermore, the $20 C R$ can be used as a kind of 'time machine' to study historical weather events.

In this study, we analysed different atmospheric variables from the $20 \mathrm{CR}$ data set to assess on the one hand the synoptic weather situation, in particular the location and development of cyclones in the North Atlantic (NA) and European sectors during June 1944; on the other hand, the 20CR was used to describe surface winds and associated wind-generated waves that could have seriously endangered the ships and paratroopers in the English Channel region. Furthermore, atmospheric moisture is used to estimate the probability of bad visibility, cloud coverage, or even precipitation.

\section{Surface cyclones and associated high wind speeds in the $20 \mathrm{CR}$ ensemble}

To further examine the synoptic weather situation during June 1944, the cyclone identification algorithm developed by Wernli and Schwierz (2006) was applied to the $20 \mathrm{CR}$ ensemble data set. In this algorithm, a surface cyclone is identified as the finite area that surrounds a local minimum in sea-level pressure (SLP) and is enclosed by the outermost closed SLP contour. Based on this scheme, we compute measures of cyclone frequency and intensity. Relative cyclone frequency is obtained by dividing the number of six-hourly periods affected by a cyclone by the total number of six-hourly intervals in the analysis period. Furthermore, SLP minima of the identified cyclones are used as a measure of their intensity. To take the geographical SLP variability into account the cyclone field SLP minima are normalised by subtracting the local SLP climatology. For each 20CR ensemble member, monthly anomalies of these parameters are derived by subtracting the climatological mean for June months in 1871-2008 from the mean for June 1944. As a result, we obtained the storminess with respect to cyclone frequency (and cyclone intensity, respectively).

Cyclones are typically associated with enhanced wind speeds along their frontal zones, which were a main concern of the D-Day forecasting team. Hence, to quantify the storminess of June 1944 with respect to wind, anomalous maximum near-surface wind speeds (i.e. wind at the pressure level 0.995 times the surface pressure, corresponding to a height of about 30-40m above ground) are computed for

the months of June in the period 1871-2008 based on the $20 C R$ ensemble data set.

\section{Early June 1944 in 20CR and historical weather charts}

In this section, we provide only a brief overview of the weather dynamics during D-Day and the preceding days, because earlier studies have investigated the meteorological situation (e.g. Douglas, 1952; ECMWF, 2004). The purpose is rather to show that the $20 \mathrm{CR}$ is able to capture the main features of the D-Day weather, compared with historical weather charts provided by the Met Office.

According to historical weather charts, two relatively weak surface cyclones were located over the NA on 3 June 1944 (0700 UTC): one south of Iceland, heading towards the British Isles, and another one east of Newfoundland (Figure 1(a)). At this time, the English Channel region was located between two frontal zones. The synoptic situation depicted in the historical charts is captured by the $20 \mathrm{CR}$, with a cyclone centre east of Newfoundland and the possibility of a second cyclone south of Iceland, although not visible as a closed SLP contour in Figure 2(a). Based on the weather situation on the morning of 3 June, the development of the weather that was to be expected for 5 June was still too uncertain to justify a postponement of the landing. However, the weather charts for 1800 UTC (not shown) were unequivocal to postpone

\section{(a) 3 June 1944}

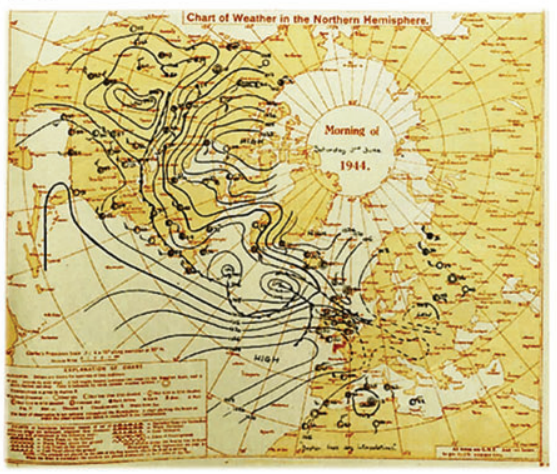

\section{(c) 5 June 1944}

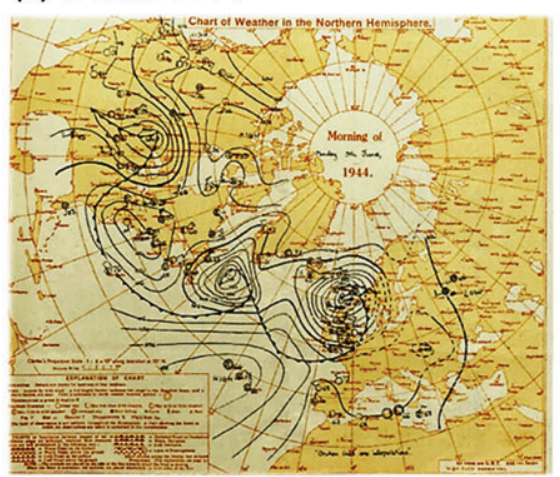

the landing by 1 day (Douglas, 1952). Due to the rapid movement of the cyclones, the cyclones were expected to pass the Channel region on the morning of 5 June.

For the period in early June 1944 analysed in this section, the ensemble spread among the 56 SLP fields of the 20CR for the NA and European sectors is generally small and none of the fields shows a fundamentally different pattern; in particular, the ensemble members hardly differ in the spatial extent of the Azores high. It is therefore sufficient to analyse the ensemble-mean SLP fields in Figure 2, without studying all ensemble members individually.

On 4 June (0700 UTC) the centre of the eastern cyclone, which had rapidly deepened, was located northwest of Scotland (Figure 1(b)). At the same time, another cyclone was already forming near Newfoundland. The 20CR (Figure 2(b)) again agrees well with the historical chart. In the afternoon of 4 June, the cold front associated with the deep cyclone over Scotland was located over Great Britain (not shown). An increase in atmospheric moisture over the English Channel region (Figure $3(d)$ ) was associated with the approaching cold front, and near-surface wind speed increased substantially over the course of the day (Figure 3(a)).

At the break of dawn of 5 June, rain was falling from overcast skies and gale-force winds drove large waves to the beaches of the Normandy. The gloomy forecast made at Dunstable Meteorological Centre thus proved to be well justified. The cyclone

\section{(b) 4 June 1944}

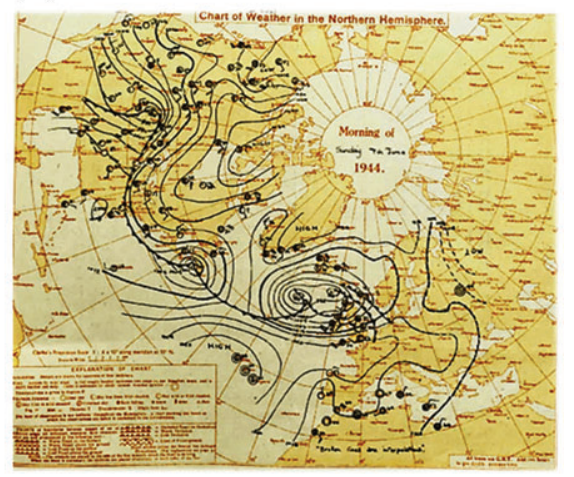

\section{(d) 6 June 1944}

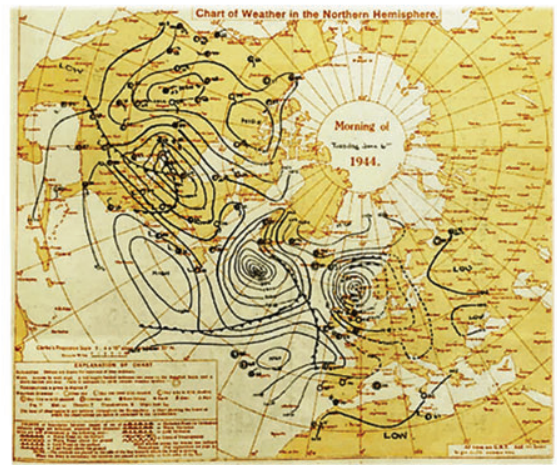

Figure 1. Synoptic situation on (a) 3 June 1944 (0700 UTC), (b) 4 June (0700 UTC), (c) 5 June (0700 UTC) and (d) 6 June (0700 UTC) according to historical weather charts by the Met Office. 
(a) 3 June 1944

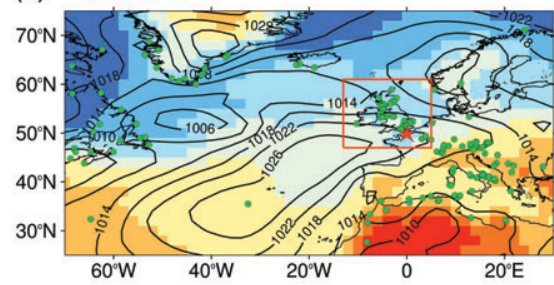

(c) 5 June 1944

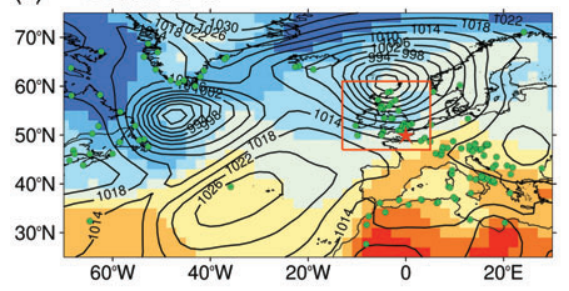

(b) 4 June 1944

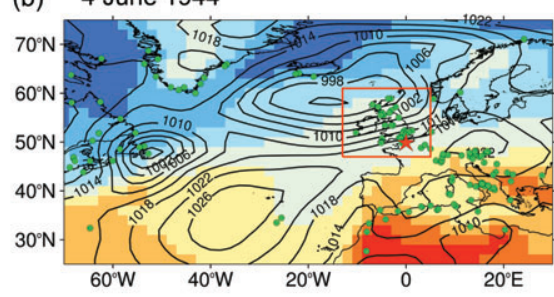

(d) 6 June 1944

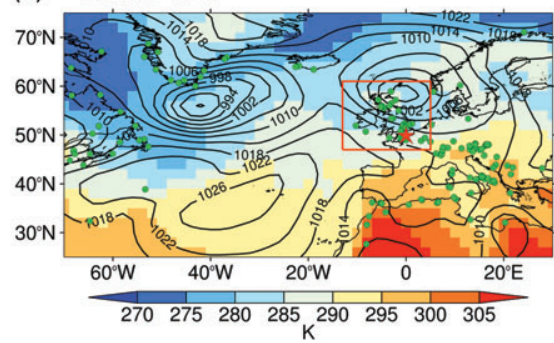

Figure 2. Synoptic situation on (a) 3 June 1944 (0600 UTC), (b) 4 June (0600 UTC), (c) 5 June (0600 UTC) and (d) 6 June (0600 UTC) according to the 20CR ensemble mean: SLP (in hPa; contour lines) and near-surface potential temperature (in K; colour shade). Green dots indicate the locations of the surface pressure and SLP observations that were assimilated into the 20CR at the respective time steps - based on version 2 of the International Surface Pressure Databank (see Compo et al., 2011). The 20CR Great Britain grid cells $\left(12^{\circ} \mathrm{W}-4^{\circ} \mathrm{E}, 48^{\circ} \mathrm{N}-60^{\circ} \mathrm{N}\right)$ are framed by a red box. The location of the Normandy landing beaches is marked with a red star.

situated northwest of Scotland on 4 June was slowly moving eastward on 5 June and the cyclone centre was located slightly to the northeast of Scotland at 0700 UTC (Figure 1(c)). At the same time, the cyclone that had formed over Newfoundland on 4 June was further deepening on 5 June and moving eastward. However, its eastward movement was providing enough time of fair weather to launch the landings on 6 June. Again, the 20CR captures well the main features of the synoptic situation (Figure 2(c)).

The decision to launch the assault on 6 June was made in the morning of 5 June. For the German forces watching their defenses, it was difficult to foresee that this was the moment the Allied armies had planned to invade. Moreover, due to the high wind speeds the reconnaissance aircraft of the German air force stayed on the ground and the German forces thus failed to notice the immediate danger of the situation.

On the morning of 6 June, the deep cyclone north of Scotland, influencing the weather in the English Channel region, slowly moved further eastward and became less deep (Figures 1(d) and 2(d)). Compared with the preceding 2 days, the near-surface wind was weaker (Figure 3(a)) and the airborne forces benefited from the improved near-surface visibility along the Normandy coast (Figure $3(\mathrm{~b})$ ). The $20 \mathrm{CR}$ indicates a drying of the atmosphere over the Channel on 6 June (Figure 3(d)). However, the 20CR further indicates the possibility of low clouds over the Normandy landing beaches (Figure 3(c)). Indeed, historical photographs show clear evidence of overcast conditions while the Allied forces were crossing the 178 Channel.
In summary, (i) the synoptic situation in early June 1944 was characterised by a succession of cyclones passing north of the English Channel, heavily influencing the weather in that region, and (ii) the $20 \mathrm{CR}$ agrees well with historical weather charts provided by the Met Office.

\section{The storminess of June 1944}

Montgomery (1948), Ambrose (1994) and Fleming (2004) stressed the uncommonly unsettled and stormy weather conditions during the D-Day landing of June 1944 and during the preceding days; although, neither the study of Montgomery nor that of Ambrose is strictly speaking a meteorological study. The aim of this section is to assess, on the basis of the 20CR ensemble data set, whether June 1944 was anomalously stormy compared with the climatology.

According to the classification system of British Isles weather types by Lamb (1972), which distinguishes 27 different circulation patterns based on surface synoptic weather charts, June 1944 was dominated by cyclonic weather and westerly flow. This flow type is typically associated with cool and cloudy conditions in summer, with changeable weather and variable wind directions due to the passage of cyclones (Barry and Chorley, 2003). Compared with the monthly mean percentage frequencies of cyclonic and westerly conditions for June in 1861-1943, which are $13 \%$ and $15 \%$, respectively, the values for June 1944 were clearly higher (23 and $27 \%)^{1}$. Also the purely anticyclonic

${ }^{1}$ Numbers based on the complete series of Lamb's weather-type classification, which is available online at http://www.cru.uea.ac.uk/cru/ data/lwt/ (last access: October 2013). weather type (10\% for June 1944), which is typically associated with warm and dry weather conditions in summer, was significantly underrepresented with respect to the 1861-1943 mean value of 21\%. Moreover, the sharp increase in the frequency of westerly weather types that takes place in midJune in the climatological mean (Barry and Chorley, 2003) apparently started approximately half a month earlier in June 1944. Thus, this early shift in the prevailing flow regime might have led to disturbed weather conditions over the British Isles.

Figure 4 shows anomalies in relative cyclone frequency for June 1944 in the NA and European sectors, based on the 20CR ensemble data set. Although there is a region of anomalously high relative cyclone frequency (greater than 30\%) centred between northern Great Britain and southern Scandinavia, the English Channel region was not directly affected by anomalously frequent cyclones. In a region over the NA west of the British Isles, the relative cyclone frequency was even reduced by approximately 10-30\%. The cyclones hitting the British Isles in June 1944 were more intense than usual, with regard to the cyclones' SLP minima (not shown). Furthermore, during June 1944 the maximum near-surface wind speed was anomalously high in many parts of Great Britain, even though again not directly in the region of the English Channel (not shown).

However, considering the climatological mean relative cyclone frequency of approximately $15-25 \%$ (Figure 4) in the aforementioned region of increased cyclone frequency between northern Great Britain and southern Scandinavia, the pronounced positive anomaly of about $30 \%$ denotes that this region was affected by cyclones during more than half of June 1944. Because the surface winds associated with extratropical cyclones are highest along the frontal zones, the cyclone fields (defined in this study by the outermost closed isobar; see section 'Surface cyclones and associated high wind speeds in the 20CR Ensemble') do not necessarily cover all areas with high winds. Bengtsson et al. (2009), who studied the spatial relation between cyclone and wind fields for intense extratropical Northern Hemisphere winter cyclones at different lifecycle stages based on the European Centre for Medium-Range Weather Forecasts 40 Year Reanalysis, found that at the state of maximum cyclone intensity the highest wind speeds are, in general, found behind and to the right of the cyclone centre in the area after the occluding cold front. Thus, the increased number of cyclones that passed to the north of the English Channel region in June 1944 very likely also affected the weather in the Normandy landing area and required the forecasters' constant alertness and vigilance, especially because the exact 
(a)

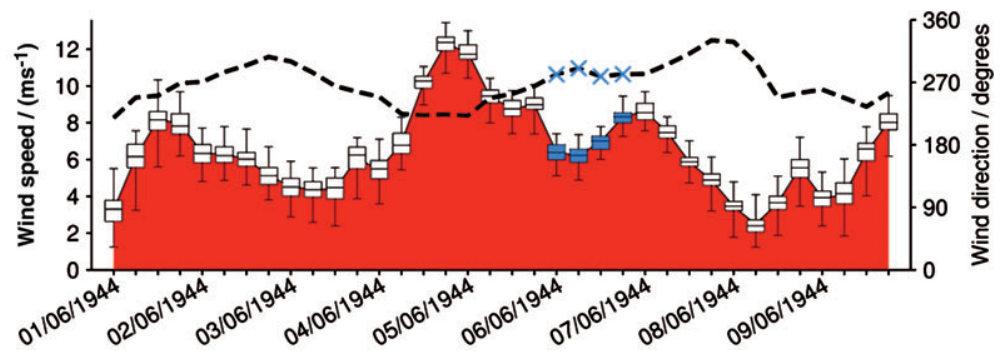

(b)

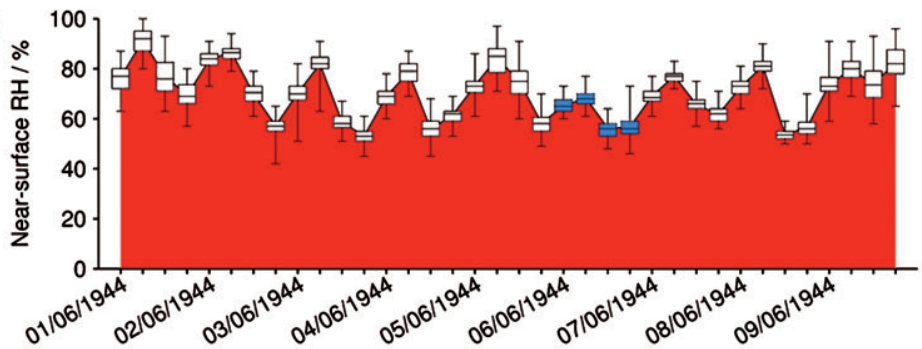

(c)

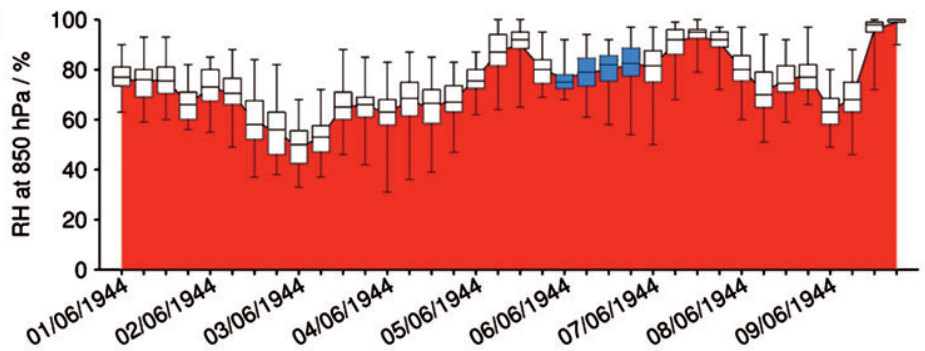

(d)

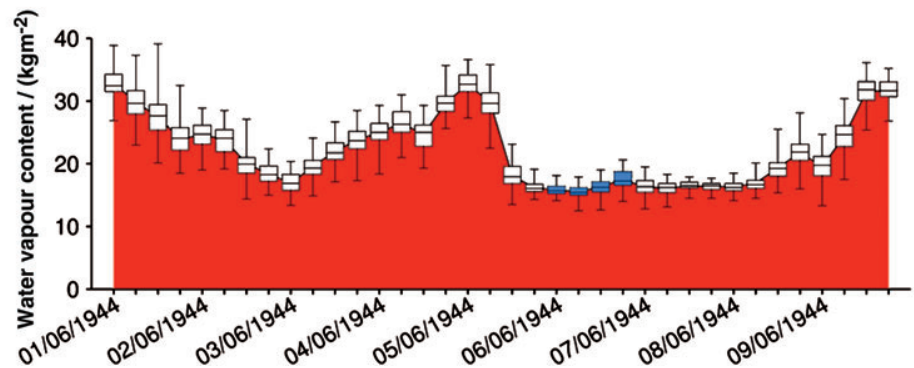

Figure 3. (a) The 20CR ensemble distribution (box plots give minimum, lower quartile, median, upper quartile, and maximum; the red area denotes the ensemble mean) of six-hourly near-surface wind speed (in ms ${ }^{-1}$; lowest model level) for the 20CR grid cell closest to the Normandy landing beaches and the period 1-9 June 1944 (the day of the Normandy landing is marked in blue). The dashed curve gives the corresponding temporal evolution of the 20CR ensemble-mean near-surface wind direction (in degrees from north). (b) Near-surface relative humidity (RH; in \%), (c) RH at $850 \mathrm{hPa}$ (in \%), and (d) atmospheric water vapour content (in $\mathrm{kgm}^{-2}$ ).

pathways of the cyclones were not known at that time.

Figure 5 shows that both cyclone frequency and maximum near-surface wind speed over the British Isles were anomalously high during June 1944 compared with the climatological average for all June months in 1871-2008: regarding the 20CR ensemble mean, the cyclone frequency (maximum near-surface wind speed) in June 1944 was the seventh (ninth) highest in the 138-year period 1871-2008.

\section{Conclusions}

The $20 \mathrm{CR}$ has proved to be a very effective 'time machine' to explore the weather in early June 1944, when World War II reached a turning point with the Allied invasion of

In this study, the 20CR was used to address two distinct aspects of the D-Day weather. (i) How well is the synoptic and mesoscale evolution at the beginning of June 1944 captured by the 20CR compared with historical weather analyses? (ii) How exceptional was the storminess of June 1944, expressed by cyclone frequency and near-surface wind speed, compared with the 20CR climatology? Indeed, this month is described as an unusually stormy month

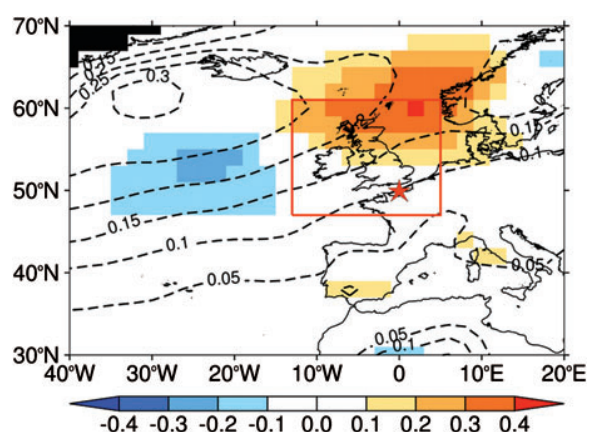

Figure 4. The 20CR ensemble-mean anomalous relative cyclone frequency for June 1944 (colour shade). Anomalies are calculated by subtracting the climatological mean for June months in 1871-2008 (dashed contours), for each 20CR ensemble member and grid cell. The 20CR Great Britain grid cells $\left(12^{\circ} \mathrm{W}-4^{\circ} \mathrm{E}, 48^{\circ} \mathrm{N}-60^{\circ} \mathrm{N}\right)$ are framed by a red box. The location of the Normandy landing beaches is marked with a red star. Black grid cells show regions where the $20 C R$ orography exceeds $1500 \mathrm{~m}$ asl.

in historical records. This information should be taken with a grain of salt, because public perception is often strongly influenced by single extreme weather events. However, it is well documented that the weather in the first week of June was very unsettled, with a 'train' of cyclones crossing the Atlantic. As a rough estimate, one third of June 1944 was characterised by well-founded influence of cyclonic activity over the northeast Atlantic, Great Britain and northern France.

When using the $20 \mathrm{CR}$, the current controversial discussion concerning the quality of the 20CR, in particular prior to 1950, is relevant. For example, Krueger et al. (2013; 2014) found, concerning storminess over the northeast Atlantic, considerable disagreement between the 20CR and observations prior to 1950 . In contrast to Wang et al. (2014), who showed that storminess in the NA and European sectors derived from the 20CR agrees well with observations back to about 1893.

For analysing cyclones in the $20 \mathrm{CR}$, the individual ensemble members should be used rather than the ensemble-mean analyses (Wang et al., 2012). Thus, we applied the objective cyclone identification and tracking scheme of Wernli and Schwierz (2006) to each of the 20CR ensemble members, which further allowed us to produce an uncertainty estimation of our results.

The main results of this study can be summarised as follows:
- The 20CR maps agree well with the historical weather charts by the Met Office (Figures 1 and 2). The synoptic situation was characterised by a succession of extratropical cyclones passing north of the English Channel and influencing the weather in that region, only permitting the landing in a short inter-frontal clearing. Slight differences 
(a)

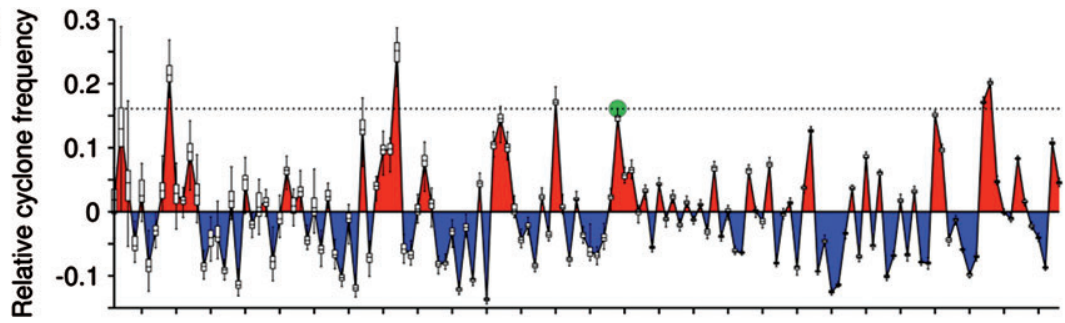

(b)

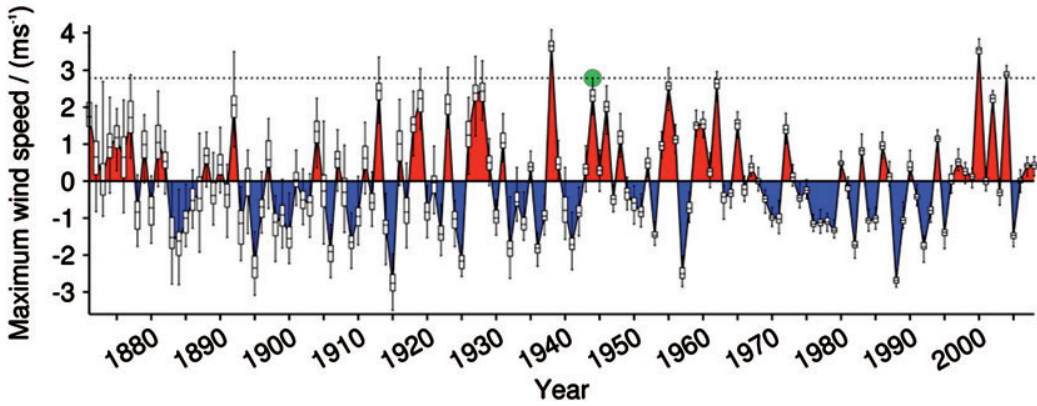

Figure 5. Spatial average for the $20 \mathrm{CR}$ Great Britain grid cells $\left(12^{\circ} \mathrm{W}-4^{\circ} \mathrm{E}, 48^{\circ} \mathrm{N}-60^{\circ} \mathrm{N}\right)$ of anomalous (a) relative cyclone frequency and (b) maximum near-surface wind speed (in $\mathrm{ms}^{-1}$ ) for June months in 1871-2008. Box plots indicate minimum, lower quartile, median, upper quartile, and maximum of the 20CR ensemble distribution and the blue and red areas denote the ensemble mean. June 1944 is marked with a green circle and a dotted line.

exist between $20 C R$ and historical maps with regard to position and intensity of NA cyclones, but the hazardous weather on 5 June 1944 and the clearing on 6 June 1944 is well captured by the 20CR (Figure 3).

- The climatological analysis of cyclone activity based on the 20CR reveals for June 1944 patches of increased cyclone frequency and wind maxima, as well as reduced cyclone-field SLP minima, over and northeast of Great Britain (Figure 4). Compared with the 20CR climatology, June 1944 ranks seventh with respect to cyclone frequency over the British Isles, and ranks ninth concerning maximum near-surface wind speed (Figure 5).

Our study also illustrates that, despite the controlling influence humans try to exert, world history is in the first instance often a game of dice rather than strategy. In the case of the D-Day forecasts, it was the role of meteorology to at least understand the rules of this game well enough to predict its outcome some days in advance, that is, to give the military commanders the best possible strategic starting point. Hence, to put it in the words of the British meteorologist Reginald Sutcliffe: Meteorologically, the occasion was remarkable not only for the degree of dependence on the weather but also the planned dependence on weather forecasts (Shaw and Innes, 1984).

\section{Acknowledgements}

We would like to thank Mark Beswick and Kate Willett from the Met Office for providing historical weather charts (shown in Figure 1), the Meteorological Magazine article by Douglas (1952) and for pointing to an interesting overview of the role of the Met Office in preparation for D-Day (http://www.metoffice.gov.uk/archive/ d-day-role-of-the-met-office). Support for the Twentieth Century Reanalysis Project data set is provided by the US Department of Energy, Office of Science Innovative and Novel Computational Impact on Theory and Experiment (DOE INCITE) programme, and Office of Biological and Environmental Research (BER), and by the National Oceanic and Atmospheric Administration Climate Program Office. Finally, we would like to thank two anonymous reviewers who provided valuable comments and hence contributed in substantially improving this article.

\section{References}

Ackerman ST, Knox JA. 2006. Meteorology: Brooks/Cole-Thomson Learning: Pacific Grove, CA, 512 pp.

Ambrose S. 1994. D-Day June 6, 1944: The Climactic Battle of World War II. Simon and Schuster: New York, NY.

Atkinson R. 2013. The road to D-Day. http://www.foreignaffairs.com/articles/139455/rick-atkinson/the-road-to-dday (accessed 10 June 2014).

Barry RG, Chorley RJ. 2003. Atmosphere, Weather, and Climate. Routledge Chapman \& Hall: London, $472 \mathrm{pp}$.

Bengtsson L, Hodges KI, Keenlyside $\mathbf{N}$. 2009. Will extratropical storms intensify in a warmer climate? J. Clim. 22: 2276-2301.

Compo GP, Whitaker JS, Sardeshmukh PD et al. 2011. The Twentieth Century Reanalysis project. Q. J. R. Meteorol. Soc. 4: 1-28.

Cox JD. 2002. Storm Watchers: The Turbulent History of Weather Prediction Understanding the Atmosphere, 2nd Edition. from Franklin's Kite to El Niño. Wiley \& Sons: New York, NY, 252 pp.

Douglas CKM. 1952. Forecasting for the D-Day landings. Meteorol. Mag. 81: 161-171. ECMWF. 2014. Revisiting the meteorology of the D-Day period, using a modern analysis and forecasting system. http://www. ecmwf.int/en/research/projects/era-clim/ d-day-analyses (accessed 13 June 2014).

Fleming JR. 2004. Sverre Petterssen, the Bergen School, and the forecasts for D-Day. Proceedings of the International Commission on the History of Meteorology, Waterville. pp 75-83.

Krueger O, Schenk F, Feser F et al. 2013. Inconsistencies between long-term trends in storminess derived from the $20 \mathrm{CR}$ reanalysis and observations. J. Clim. $\mathbf{2 6}$ 868-874.

Krueger O, Feser F, Bärring L et al. 2014 Comment on 'Trends and low frequency variability of extra-tropical cyclone activity in the ensemble of twentieth century reanalysis' by Xiaolan L. Wang, Y. Feng, G. P. Compo, V. R. Swail, F. W. Zwiers, R. J. Allan, and P. D. Sardeshmukh. Climate Dynamics, 2012. Clim. Dyn. 42: 1127-1128. doi:10.1007/s00382-013-1814-9

Lamb HH. 1972. British Isles Weather types and a register of daily sequence of circulation patterns, 1861-1971. Geophys. Mem. 116: 85 pp.

Montgomery B. 1948. Normandy to the Baltic: Twenty-First Army Group. Houghton Mifflin: Boston, MA.

Petterssen S. 2001. In Weathering the Storm: Sverre Petterssen, the D-Day Forecast, and the Rise of Modern Meteorology. Fleming JR (ed.). American Meteorological Society: Boston, MA, 329 pp

Rayner NA, Parker DE, Horton EB et al. 2003. Global analyses of sea surface temperature, sea ice, and night marine air temperature since the late nineteenth century. J. Geophys. Res. 108: 4407. doi:10.1029/2002JD002670

Shaw RH, Innes W. 1984. Some Meteorological Aspects of the D-Day Invasion of Europe, 6 June 1944. American Meteorological Society: Boston, MA.

Stagg JM. 1971. Forecast for Overlord, June 6, 1944. Littlehampton Book Services Ltd: Addlestone, UK.

Wang XL, Feng Y, Compo GP et al. 2012. Trends and low frequency variability of extra-tropical cyclone activity in the ensemble of twentieth century reanalysis. Clim. Dyn. 40: 2775-2800. doi:10.1007/ s00382-012-1450-9

Wang XL, Feng Y, Compo GP et al. 2014. Is the storminess in the Twentieth Century Reanalysis really inconsistent with observations? A reply to the comment by Krueger et al. (2014). Clim. Dyn. 42: 1113-1125. doi:10.1007/s00382-013-1828-3

Wernli H, Schwierz C. 2006. Surface cyclones in the ERA-40 dataset (1958-2001). Part I: novel identification method and global climatology. J. Atmos. Sci. 63: 2486-2507.

\section{Correspondence to: Christoph Welker} christoph.welker@giub.unibe.ch (c) 2014 Royal Meteorological Society doi:10.1002/wea.2339 